\title{
The Impact of Road Construction Program: Evidence from East Java, Indonesia
}

\section{Irim Tiara Puri ${ }^{1}$ and Rumayya ${ }^{2}$}

${ }^{1}$ Faculty of Economics and Business, University of Indonesia, Jalan Salemba Raya 4, Jakarta Pusat 10430, Indonesia

${ }^{2}$ Faculty of Economics and Business, Airlangga UniversityJalan Airlangga 4-6, Surabaya 60286, Indonesia

\section{Abstract}

The purpose of the Jalan Lintas Selatan (JLS) construction program is to reduce the inequality between the southern and the northern area in East Java. In order to measure the success of the road construction program, this study aims to evaluate the socioeconomic impact on villages passed by the JLS. Especially in Pacitan, Trenggalek and Tulungagung districts. This study uses Propensity Score Matching (PSM) and Difference in Difference (DID) to evaluate the causal impact, while the data are obtained from survey Potensi Desa (PODES) in 2008, 2011 and 2014.

Corresponding Author:

Irim Tiara Puri

Received: 10 February 2019

Accepted: 14 March 2019

Published: 28 March 2019

Publishing services provided by

Knowledge E

(c) Irim Tiara Puri and

Rumayya. This article is

distributed under the terms of

the Creative Commons

Attribution License, which

permits unrestricted use and

redistribution provided that the

original author and source are

credited.

Selection and Peer-review under the responsibility of the ICIEBP Conference Committee.

\section{G OPEN ACCESS}

The findings of this study show that the road construction program has a positive impact to the regions. Due to the construction, population density, investment and job opportunities increased. It also shortens the distance of schools to the village center, especially senior high school. Interestingly it is also decreased length to karaoke. However, we also find that the road construction reduce the Own-Source Revenue (Pendapatan Asli Daerah) of the village government.

Keywords: road construction program, Jalan Lintas Selatan, Propensity Score Matching, Difference in Difference, village socioeconomic.

\section{Introduction}

The East Java regions can be grouped by the location into two groups, the northern area and the southern area. The nothern part consists of eight regions, which are Tuban, Lamongan, Gresik, Sidoarjo, Pasuruan, Probolinggo, Bondowoso, Situbondo, Surabaya, Pasuruan, and Porobolinggo. The southern part also consists of eight regions, which are Pacitan, Trenggalek, Tulungagung, Blitar, Malang, Lumajang, Jember, and Banyuwangi. Although East Java categorized as developed province relative to the other province outside Java according to its macroeconomics indicator value, there is still a quite wide inequality between southern and nothern area due to the different ability to develop (Warda, 2013). One of the most important infrastructure to boost the regions' economy 
is a road. A well-built road could be a good investment to reduce the inequality, since it can increase economic activity in the regions that will lead to poverty alleviation (Lokshin and Yemtsov, 2005).

Bina Marga Public Service of East Java (2015) says that several potential areas in southern East Java still lagged behind because of the limited road across the regions. Besides this fact, the government is struggling to reduce the inequality by making more roads in the southern. They try to design a road construction program called Jalan Lintas Selatan (JLS). The JLS has started to build since 2002. In 2015, the roads already 673,88 $\mathrm{km}$ long and targeted to be done in 2019. Picture 1.2 shows the JLS that lay across eight districts in southern East Java. Three of eight districts that already got the roads are Pacitan, Trenggalek, and Tulungagung. The construction program in Pacitan is about 95.90\%, while in Trenggalek is $31.48 \%$ and Tulungagung is $15.52 \%$.

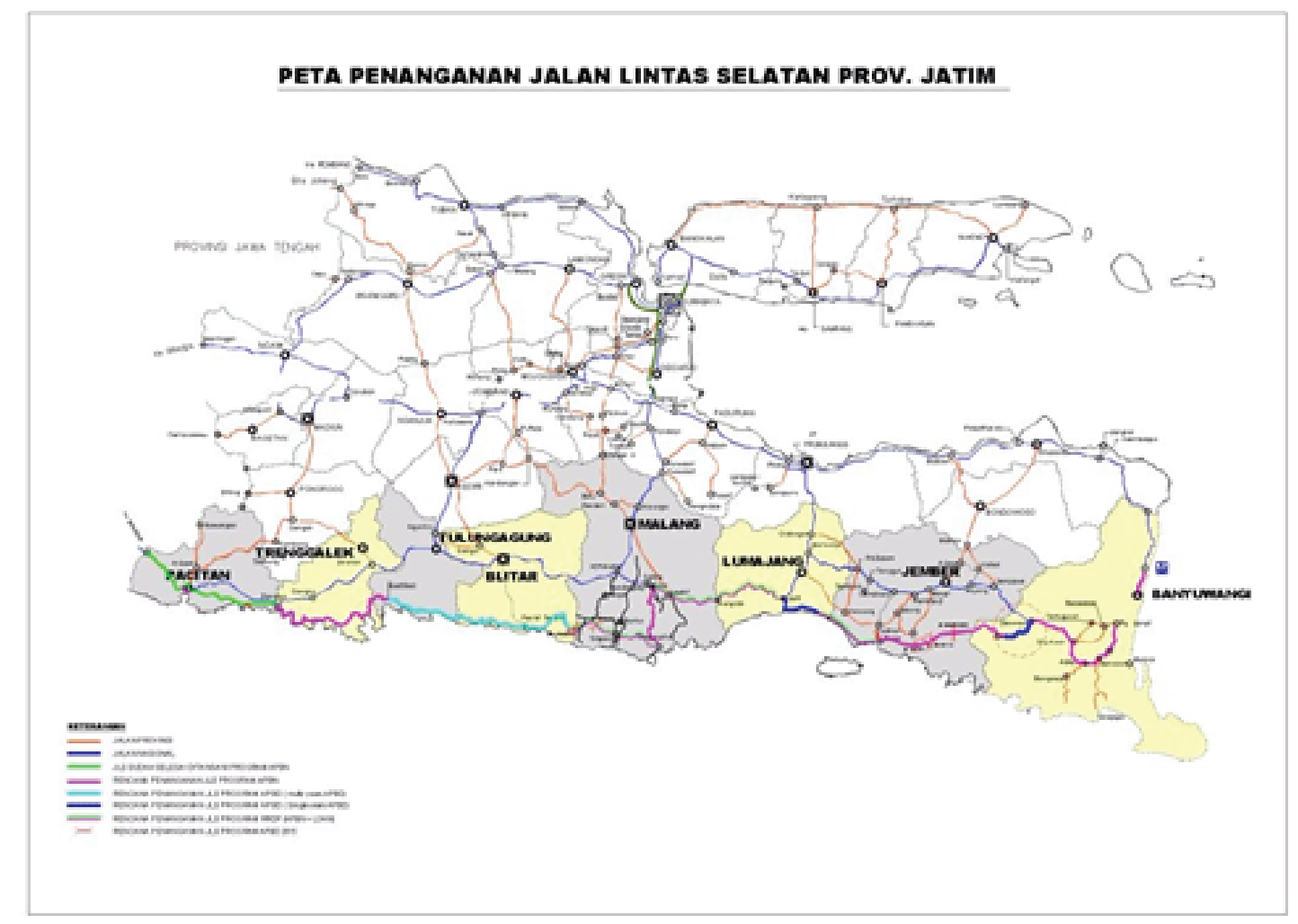

Figure 1: Map of the South Cross Road through eight districts in the south of East Java (Sumber: Dinas PU Bina Marga Jawa Timur, 2015).

The JLS construction program is expected to develop East Java equally and eliminate the gap between the southern and northern area, as well as improving the socioeconomic conditions of the community. However, the road construction program does not always have a positive impact (Warda, 2013). Therefore, the objective of this research is to evaluate the impact of the JLS construction program, especially the socioeconomic 
impact, on villages in three districts of southern East Java i.e. Pacitan, Trenggalek, and Tulungagung.

\section{Literatur Review}

Based on the literature studies, road infrastructure benefits the community economically and socially. The New Growth Theory explains that infrastructure is kind of input which could drive the economy (Hulten and Schwab, 1991). The availability of the roads infrastucture increase the efficiency in production activity by improving the location accessability and reducing the input and distribution cost (Barro, 1990: 53; Khanker et al., 2009). This means that the road construction have a positive economic impact to the society.

Socially, the road infrastructure provides a lot of amenities such as (1) serves the individual or the society, (2) clarify the information exchange, (3) makes people easier to access the entertainment, (4) expands the social program's scope, (5) cuts down the distances between housing area, public facilities, and offices, also (6) facilitates the social assistance programs (Nasution, 1994; Siregar, 1990).

Farris and Harding in Anwar and Tito (1996) says that the construction of road infrastructure can generate social benefits as well as social costs. The social benefits are: (1) growing number of job opportunities, which in turn can increase the income; (2) reduce time consumptions; (3) expands the agricultural commodity markets; (4) exchanges barter with market transactions; and (5) changes the community behavior. While the social costs faced by rural community are (1) road accidents, (2) community discharge, (3) natural resource exploitation, and lifestyle changes of rural society (Adler 1983: 65).

Empirical studies put the same things as the literature studies. It stated that road construction can reduce poverty by increasing quantity of agricultural production, wages, and output prices (Khandker et al., 2009). It is even can increase women's wages in regions (Lokshin and Yemtsov, 2005). On the other hand, Lokshin and Yemtsov (2005) says that the exitence of roads led to sectoral changing from agricultural base to industrial base, marked with the increasing number of industrial job opportunities. That kind of reality forces people to move from agricultural to non-agricultural sectors (Mu and Walle, 2009). 


\section{Data and Method}

The data uses in this study are obtained from survey Potensi Desa (PODES) in 2008, 2011, and 2014. The survey conducted by Central Bureau of Statistics at village level (including nagari in West Sumatra, kelurahan, and UPT) in all sub-districts or districts on Indonesia. Villages classified as an operational village if they have a clear boundary, resident, and government.

Using Propensity Score Matching (PSM) and Difference-in-Difference (DID) methods, we evaluate the impact of the road construction program to the villages in Pacitan, Trenggalek, and Tulungagung. At first, we use Probit model to estimate the Propensity Score (PScore). Then, the PScore uses to determine the villages that have a similar characteristics. Villages that have similar PScore considered to have a similar characterisrics. The group then labelled as "common support". After getting the common support group, we do the balancing property test to separate the common support into two groups, treated group and untreated group. The treated group is for villages passed by the JLS, while the untreated group is for the others which do not. Some basic characteristics uses to match villages shown in Appendix 1. Therefore, we can only use sample that have very similar characteristics for the next step.

The second step in this study exploit Difference-in-Difference (DID) method to estimate the average program's impact on socioeconomic outcomes such as population density, total village's income, and many more. We estimate all the socioeconomic outcomes that available on the PODES 2011 and PODES 2014. Using the DID methods, we can minimize the bias result by controlling the unobserved time-invariant heterogeneity. DID model is down below:

$$
Y_{i t}=\alpha_{1}+\beta_{1} t+\beta_{2} D^{2011}+\beta_{3} D^{2014}+\beta_{4}\left(t \cdot D^{2011}\right)+\beta 5\left(t . D^{2014}\right)+\beta_{6} X_{i t}+\varepsilon_{i t}
$$

Where, $Y_{i t}=$ socioeconomic outcome variables

$$
\begin{aligned}
& \alpha_{i}=\text { region fixed effect } \\
& t=\text { dummy group (1=treated group; 0=untreated group) } \\
& D^{2011}=\text { dummy time } 2011(1=2011 ; 0=2008) \\
& D^{2014}=\text { dummy time } 2014(1=2014 ; 0=2008) \\
& \epsilon_{i t}=\text { error }
\end{aligned}
$$

The $\beta_{1}$ is the outcome difference between the treated group and untreated group. The $\beta_{2}$ is the outcome difference in terms of time, between 2008 and 2011. The $\beta_{3}$ is the outcome difference in terms of time, between 2008 and 2014. While $\beta_{4}$ and $\beta_{5}$ are the 
coefficient that reflect the oucome difference in terms of intervention and time. Those coefficient show the impact of the program.

TABLE 1: The DID Estimation Results.

\begin{tabular}{|c|c|c|}
\hline Outcome Variables & Coef. & Robust Std. Err. \\
\hline \multicolumn{3}{|l|}{ Demography: } \\
\hline Density (2011) & $52.7443^{* * *}$ & 15.1015 \\
\hline Density (2014) & $37.0739 * *$ & 18.8649 \\
\hline \multicolumn{3}{|l|}{ Sosial: } \\
\hline Closest distance to nearest highschool (2011) & $-1.0542^{* *}$ & 0.5380 \\
\hline Closest distance to nearest highschool (2014) & $-0.8550^{*}$ & 0.5192 \\
\hline Closest distance to nearest highschool SMK(2011) & $-3.7964^{* * *}$ & 1.3587 \\
\hline Closest distance to nearest highschool SMK(2014) & $-2.8995^{* * *}$ & 0.9102 \\
\hline Closest distance to nearest Karaoke(2011) & $-8.6767^{* * *}$ & 2.3928 \\
\hline Closest distance to nearest Karaoke (2014) & $-17.1038^{* * *}$ & 2.6702 \\
\hline \multicolumn{3}{|l|}{ Ekonomi: } \\
\hline Total Income of the village (2011) & $-0.0197^{* * *}$ & 0.0051 \\
\hline Total Income of the village (2014) & $-0.0178^{* *}$ & 0.0079 \\
\hline
\end{tabular}

\section{Result and Discussion}

The PSM estimation generate the Propensity Score (PScore) that will be used in balancing property test. The result of balancing property test obtain a common support which consists of 599 villages in Pacitan and 539 villages in Trenggalek and Tulungagung. Furthermore, using the 539 villages that have similar characteristics as a sample we employ DID to value the impact. The identical sample could drop probability of biased results. So if there is a different outcomes between the two groups, it must be caused by the intervention or the program.

Using the DID, we estimate all the socioeconomic variables in PODES but only several variables remain significant. The outcomes are population density, distance to school facility, distance to karaoke, and the total income of the village as we can see in Table 1. There are three findings in this study. First, the road construction program significantly affect the population density in each village. In 2011 number of residents increased by 53 people per $\mathrm{km}^{2}$, while in 2014 increased by 37 people per $\mathrm{km}^{2}$. This because the increasing number of workers on construction sector that come into the region along with the programs. Mostly, they come from other region. Second, the program significantly cut off the distance from the residence to school (especially SMA and SMK) and karaoke (entertainment facility). So it just takes little time to get 


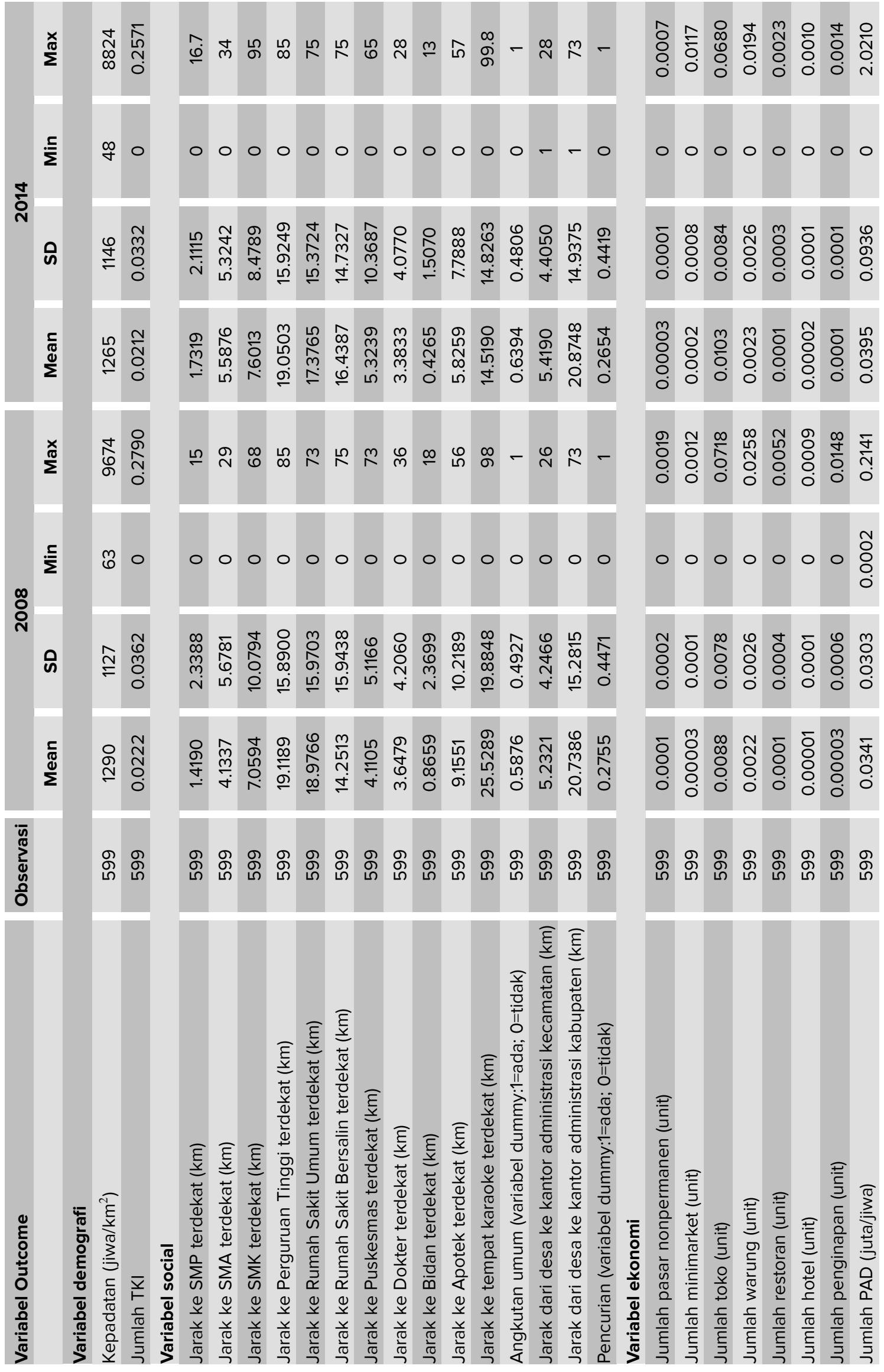


onto school or karaoke, since the roads make the facilities accessed easily. Third, the program significantly reduce the amount of village's own-source income because the construction wipe out the village's income source like the crooked land.

\section{Conslusion and Suggestion}

The socioeconomic impact of road construction program in southern East Java, especially in Pacitan, Trenggalek and Tulungagung, increase the population density, the attractiveness to investment, and reduce the distance to the senior high school (SMA and SMK) and karaoke (entertainment facility). Unfortunately, it also decrease of the village's own-source income. Based on these findings, the government is expected to complete the construction immediately, since the roads still partially done due to the limited budget from central and regional government. To overcome the problem, the government need to get an extra loan to finance the road construction.

\section{References}

[1] __ (2015). Laporan Akhir Tahun 2015 Pembangunan Jalan \& Jembatan Lintas Selatan Provinsi Jawa Timur. Dinas Pekerjaan Umum Bina Marga Provinsi Jawa Timur

[2] Adler, A. Tanpa Tahun. Evaluasi Ekonomi Proyek-Proyek Pengangkutan. Terjemahan oleh Paul Sitohang. 1983. Jakarta: UI Press

[3] Anwar, A. \& Tito, M. (1996). Sistem Transportasi di Kawasan Metropolitan Jakarta dan Implikasinya Kepada Kesejahteraan Golongan Masyarakat Kecil. Jurnal Perencanaan Pembangunan Wilayah dan Pedesaan (PWD), 2: 93-123

[4] Barro, R. J. (1990). Government Spending in A Simple Model of Endogeneous Growth. Journal of political economy, 98(5, Part 2): S103-S125

[5] Hulten, C. R., \& Schwab, R. M. (1991). Public Capital Formation and The Growth of Regional Manufacturing Industries. National Tax Journal,: 121-134

[6] Khandker, S. R., Koolwal, G. B., \& Samad, H. A. (2010). Handbook on Impact Evaluation: Quantitative Methods and Practices. World Bank Publications

[7] Lokshin, M., \& Yemtsov, R. (2005). Has Rural Infrastructure Rehabilitation in Georgia Helped the Poor?. The World Bank Economic Review, 19(2): 311-333

[8] Mu, R., \& Van de Walle, D. (2009). Rural Roads and Local Market Development in Vietnam. The Journal of Development Studies, 47(5):709-734.

[9] Nasution, M. 1994. Manajemen Transportasi. Bogor: Gahlia Indonesia 
[10] Siregar, M. 1990. Beberapa Masalah Ekonomi dan Management Pengangkutan. Jakarta: FE UI

[11] Warda, H. C. (2013). Analisis Ketimpangan Pembangunan Ekonomi Antara Wilayah Utara dan Selatan Provinsi Jawa Timur. Jurnal Pendidikan Ekonomi (JUPE), 1(3)

[12] Lampiran 1 Statistik Deskriptif Variabel Outcome Desa Sebelum dan Sesudah Proyek 